Munteán, László. "Roters, Katharina. 2014. Hungarian Cubes: Subversive Ornaments in Socialism. Zürich: Park Books. 171 pp. illus." Hungarian Cultural Studies. e-Journal of the American Hungarian Educators Association, Volume 9 (2016): http://ahea.pitt.edu DOI: 10.5195/ahea.2016.227

\title{
Roters, Katharina. 2014. Hungarian Cubes: Subversive Ornaments in Socialism. Zürich: Park Books. 171 pp. illus.
}

\section{Reviewed by László Munteán, Radboud University, Nijmegen, the Netherlands}

Katharina Roters is a German-Hungarian painter and photographer who in 2003 moved from Germany to a Hungarian village. Enamored by what she saw as an "almost absurd beauty" (166) of the houses in her new environment, she embarked on a project of systematically photographing family homes predominantly built during the so-called "Goulash Communism" of the Kádár era (1962-1989). The built environment that unfolds while leafing through Roters' book is one that most Hungarians consider imprints of embarrassing tastelessness: gable- and pyramid-roofed single-family homes with their front façades adorned with colorful geometrical ornaments. Although the historical, sociological, and political aspects of these houses have received significant scholarly attention over the past years (most recently by Molnár Virág's Building the State: Architecture, Politics, and State Formation in Postwar Central Europe, which was reviewed in vol. 7 (2014) of this journal, at:

http://ahea.pitt.edu/ojs/index.php/ahea/article/view/156 ), their ornamental features have been considered more embarrassing than worthy of serious attention. It is precisely this aesthetic dimension that takes center stage in Roters' Hungarian Cubes, which puts the architecture of the Kádár era in a fresh perspective from which both professionals and non-professionals can benefit.

The book starts in medias res, so to speak, presenting more than one hundred crystal-clear color photographs of street-facing façades arranged spaciously, one image per page, which no doubt creates a sense of monotony. While each façade offers a new composition of plastered ornaments, put together thus they look as if they were all designed with the same sensibility and mindset. Instead of emphasizing the spatial and environmental dimensions of the houses, Roters' pictures flatten out the façades to make them appear like canvases adorned with ornaments. Indeed, the houses seem to be taken out of their spatial context and presented as two-dimensional artworks in a virtual museum. Such a painterly presentation is, as Roters explains in the book's concluding essay, the result of digital post-processing. By way of retouching her analogue photos she managed to remove such "superfluous elements" (166) as branches, power cables, and satellite dishes that in her mind would have disturbed the reading of these façades as " pure signs"" (166). In other words, through isolating the façades from their lived environment Roters compels viewers to engage with them semantically, as though revealing fragments of a formerly unknown language.

By doing so, Roters makes their viewers bear witness to the existence of the façades as part and parcel of the Hungarian built environment that to this day demands to be contended with. Sorted by the type of houses that they adorn, the ornaments are presented with encyclopedic meticulousness, much like József Huszka's documentation of the ornamental vocabulary of Transylvanian peasant houses in the late nineteenth century, which architects like Ödön Lechner and Károly Kós would adopt in their visions of a national style. Though the so-

$($ (c) $)$ EY

ULIS D-Serk
New articles in this journal are licensed under a Creative Commons Attribution 4.0 International License.

This journal is published by the University Library System of the University of Pittsburgh as part of its D-Scribe Digital Publishing Program and is cosponsored by the University of Pittsburgh Press 
Munteán, László. "Roters, Katharina. 2014. Hungarian Cubes: Subversive Ornaments in Socialism. Zürich: Park Books. 171 pp. illus." Hungarian Cultural Studies. e-Journal of the American Hungarian Educators Association, Volume 9 (2016): http://ahea.pitt.edu DOI: 10.5195/ahea.2016.227

called Kádár Cubes are decisive elements of the Hungarian countryside, the ornamental vocabulary that unfolds in Roters' book strikes the reader or viewer as at once recognizable and completely unknown. This uncanny experience of seeing familiar buildings in a defamiliarized context is central to the book's unique affect on its Hungarian readership.

While many books on art and architecture start with an introductory essay, Hungarian Cubes opens with the photographs and continues with a series of short essays that put the pictures in perspective, finally concluding with the author's essay. The essays by various authors in the book's last part (144-166), some of which are written in German, address an international audience to whom the historical and sociological contexts of this architectural phenomenon is largely unknown. Roters, too, it turns out, had no preliminary knowledge of this cubic phenomenon earlier, as she writes that: "My 'outsider's view' enabled me to see these houses and their ornamentation without the ballast of intellectual and emotional significance attributed by the 'indigenous insider's view"' (166). Indeed, the decontextualized presentation of the images bespeaks the gaze of an artist more interested in their details of ornamentation than in their historical background, and the book's structure clearly attests to the author's artistic gaze.

In a short essay entitled "On the Roadside" that constitutes an elegant transition from the photographs to the subsequent historical and sociological essays, philosopher and art historian Hannes Böhringer personifies the buildings in Roters' book by likening their façades to layers of makeup that women would wear. Böhringer's essay approaches these façades with a phenomenological sensibility, as he points to the feelings and impressions that they generate. When he observes that the houses do not seem to be "rooted in the ground" (156) he implicitly reveals a very important aspect of their ornamental language, namely their potential to turn the façade into something more than an architectural surface that separates interior from exterior spaces. Many of the ornaments that cover large wall surfaces create an illusion of depth that indeed unmoors them from the ground.

Communication and media-studies scholar Zsolt Szijártó's highly informative essay outlines three major styles of single-family private home construction that existed respectively between the two world wars, in the Kádár era, and during the change of regimes in 1989. Szijártó demonstrates that this architectural type has always been an illegitimate child of Hungarian mainstream architecture. During the revival of folk culture in the 1930s such houses were criticized for their lack of authenticity, while the ideological climate of the 1950s communism recognized them as an expression of unwelcome individualism, whereas in the late 1980s they attested to an effort to turn away from Modernist functionalism. The most interesting argument in this essay, however, probes the economic and social changes during state-socialism and demonstrates how industrialization and urbanization were enforced to the detriment of infrastructure, which gave rise to the figure of the commuter who would work in the city and live in the countryside. The ornate façades, Szijártó argues, are silent memorials to the wishes of their inhabitants to become urban dwellers. "The ornamental decoration of the façades provided an opportunity for identification, or for the expression of a new, community-forming way of life" (159); this observation is supported by an interview with filmmaker and media artist József Szolnoki that follows Szijártó's essay.

Art historian Endre Prakfalvi's essay supplements Szijártó's observations by focusing on the semi-amateurish construction methods used for these houses as well as on the legacy of the pyramid roof that characterizes family homes of the Kádár era. Gradually replacing the gable roof, which was a traditional element of Hungarian village houses, the pyramid-shaped roof 
Munteán, László. "Roters, Katharina. 2014. Hungarian Cubes: Subversive Ornaments in Socialism. Zürich: Park Books. 171 pp. illus." Hungarian Cultural Studies. e-Journal of the American Hungarian Educators Association, Volume 9 (2016): http://ahea.pitt.edu DOI: 10.5195/ahea.2016.227

became standard practice by the 1970s. The design and construction of these houses did not officially require an architect, as the presence of a master mason sufficed, with the bulk of the work carried out by the inhabitant family and its friends in a cooperative venture called kaláka in Hungarian. Prakfalvi argues that the so-called "Tulip Debate" of 1975-76, sparked by the implementation of folk ornaments on a prefabricated housing project in Pécs, was already "an implicit, and even explicit, manifestation of the palpable tension between 'socialist art' and the growing need for art that is not limited by a label" (164); hence the subversive potential of this ornamental practice, as suggested by the book's subtitle. "The commuters' delight in ornamentation," Roters contends, "thus reveals itself as a type of ritualized formula, pointing a way out of the vacuum of alienation" (166).

Both Szijártó and Prakflavi point to the lack of scholarly attention paid to the vernacular reminders of Hungary's recent past, thus locating a lacuna in scholarship that Roters describes by adopting anthropologist Jan Vansina's term of "floating gap" (166), which marks the absence of discourse about the time between the recent past and the remote past. Although everyday life in socialism has been a favored topic of research over the past decade, there is indeed a gap in our understanding of the vernacular aspect of socialist architecture. By way of showcasing a "virtual village, as a place of remembrance for this epoch" (166) Hungarian Cubes offers a substantial step towards recognizing these façades as architectural heritage. In addition, the book paves the way for further research into the materiality, iconography, and function of these decorative motifs, as well as into the everyday life of the commuters who created and inhabited them. 